\title{
LEARNERS' NEED ANALYSIS OF ENGLISH FOR SPECIFIC PURPOSES OF CULINARY DEPARTMENT STUDENTS AT SMKN 3 KOTA BENGKULU
}

\author{
Annisa Ayutami \\ University of Bengkulu \\ ayutamia@gmail.com \\ Alamsyah Harahap \\ University of Bengkulu \\ alamsyahharahap18@yahoo.com \\ Syahrial \\ University of Bengkulu \\ eric.syahrial@gmail.com
}

\begin{abstract}
The design of this research is qualitative descriptive research. The purposes of this research are first to analyze the English learning needs of students in Culinary Department and second to identify what are the needs that not available in the textbook used. The subjects of this research are first the students of SMKN 3 Bengkulu 10th grade, second the English teachers who teach at the Culinary department, third alumni of Culinary department, and fourth the English language users in the field of Culinary. In this study, researchers used the needs analysis to find what are the needs and wants of students in learning English. The instruments that used in this study are questionnaires, interview questionnaires, and textbooks used in English language learning. The result of the research indicates that the students' English needs is the learning material according to their vocation and the activity that can make the students more active in the learning process. For unavailable needs are including the materials that contain more vocabulary related to culinary, text examples and tasks to suit students' abilities, and learning activities that can make students more active.
\end{abstract}

Keywords: English for Specific Purposes (ESP), Need Analysis, Vocational school

\section{INTRODUCTION}

Vocational High School or SMK (Sekolah Menengah Kejuruan) is an educational institution which focuses on developing specific skills. Generally, SMK provides several study programs for the students. SMK has a purpose to educate the students to be competent persons due to their study programs. During the study, the students are required to improve knowledge and apply their soft and hard skills into practice by following an apprentice program or PKL (Praktek Kerja Lapangan). Later, it is expected that the students will be skillful and competitive persons to enter fields of endeavor after they finish their education.

Based on the Indonesian government rule No 17 year 2013 article 80, the study program in SMK is categorized into nine: Teknologi dan Rekayasa, Teknologi Informasi dan Komunikasi, Kesehatan, Agribisnis dan Agroteknologi, Perikanan dan Kelautan, Bisnis dan Manajemen, Pariwisata, Seni Rupa dan Kriya, and Seni Pertunjukan. In terms of English teaching, the Minister of Education and Culture Regulation No. $68,69,10 / 2013$ about the basic competences of English states that English teaching in SMK is focused on developing communicative 
competence. The objective is to enable the students to communicate in the target language orally and in writing accurately and appropriately in the four language skills to support their competence in a certain 2 programs. To reach the objective, there are some factors which have to be considered such as teachers, media, and materials.

Unfortunately, most of SMK in Indonesia still have a problem related to the availability of English learning materials which are appropriate for the students. The materials that used in SMK are not specified into certain study programs, whereas English which is needed by the students in their future occupation will be different. This also happens in SMKN 3 Kota Bengkulu. This school has five study programs, they are; Computer Network Engineering Department, Broadcasting Department, Fashion Department, Culinary Department, and Beauty Department. Ideally, it should have five kinds of English learning materials for each grade that related to their study programs but in reality there are none of the materials that seems to be related to the study programs.

Teachers in SMKN 3 Kota Bengkulu use the textbook published by Pusat Kurikulum dan Perbukuan, Balitbang, Kementerian Pendidikan dan Budaya. This book consists of eighteen chapters, but each chapter only emphasized in general English material and activities that seems not suited for students in Culinary study program. All the $\mathrm{X}$ grade classes from the different study program use this book although they have the different learning needs. This condition might prevent the students to develop their skills to communicate using English in the target situation of their field works. If such condition happens, the purposes of the English teaching will not be achieved. In order to achieve the purposes, the researcher thinks that there should be an analysis of learners' need in English based on English for Specific Purposes.

Hutchinson and Waters (1987) viewed ESP as an approach, not a product, meaning that it "does not involve a particular kind of language, teaching material, or methodology" (p. 2). This might be considered the most general of the definitions. Anthony (1997) stated that, during Japan's Conference on ESP, Dudley-Evans included another feature within this definition, that "ESP is defined to meet specific needs of the learners" (p. 2). In addition, the two variable characteristics are its restriction in terms of skills to be learned and the lack of a pre-established methodology.

In line with the definitions above, ESP then should meet the learner's specific need and should make the learner's learn something based on their reason for learning by conducting a need analysis. Needs analysis (also known as need assessment) has a vital role in the process of designing and carrying out any language course, whether it is English for Specific Purposes (ESP) or general English course, and its centrality has been acknowledged by several scholars and authors. According to Iwai et al. (1999), the term need analysis generally refers to the activities that are involved in collecting information that will serve as the basis for developing a curriculum that will meet the needs of a particular group of students. It will find out the learners' needs in terms of use of the language in the target situation and the learner's needs in acquiring the language learned. The result of the analysis will be helpful for the teacher and the school in achieving the purposes of English teaching.

By observing the findings above, it is interesting then to analyze what is the English needs of Culinary Department students and to give a contribution in English teaching and learning especially to be the consideration in developing the material of English for Culinary.

\section{METHOD}

This research was a descriptive qualitative design. In conducting the research, the researcher conducted the questionnaire and interview to 50 Culinary students grade $\mathrm{X}$, five English teachers, graduates and stakeholders.

There were three instruments that were

used in this research. The first was questionnaires to gathered the data about 
learners' English needs. The questionnaire was administered to analyze the learners' English needs based on the opinion from the students, teachers and graduates. There were two different questionnaire int this research. The first questionnaire was administered to students to find out their wants and needs in English and the second questionnaire was administered to teachers and graduates to analysze about the necessities in learners' English needs.

The second instrument was interview list. There were three interview lists that were used in this research. The first interview list was used to collect the data from the teacher, the second interview list was used to collect the data from the graduates, and the third was used to collect the data from the stakeholders. students' learning styles. Those three interview lists aimed to gathered the data about the learners' needs to support the data from the questionnaires and to find out how the research findings can be use to fullfil the learners needs.

For learners need result, The data collected by questionnaire were analyzed by use $\mathrm{P}(\%)$ : f / $\mathrm{N}(100)$ formula. To support the results, the data by interview lists were described descriptively.

The third instruments was textbook that used in English learning process at Culinary department grade $\mathrm{X}$. This book was analyzed to find out what needs that not avaliable in the textbooks. After the result are obtaineds, than the researcher proposes a learning material that designed based on the comparison of the needs that avaliable in the textbook with the learners' needs. The proposed learning material was expercted to be a supplementary material that can help the teachers in learning efeectively to meet the learners' needs.

\section{RESULTS AND DISCUSSION}

\section{Learners Need}

The findings of this research showed that the needs of the culinary students is the material that contain more vocabulary and grammar related to the culinary terms and activities that can required the students to be more active. The results fifty percents of the respondents (in here the respondents are the teachers and the stakeholders) stated that the students are expected to be able to read and understand the recipe that written in English. The students are also expected to be fluent in explaining the detail of the recipe to their cook helper or the station chef. To achieve those two objectives, the students have to be fluent and have a lot of knowledge about the culinary terms. On the other hand, the findings about students proficiency showed that most of the students in grade $\mathrm{X}$ of Culinary Department have low vocabulary and grammar mastery especially the vocabulary and grammar that are related to culinary terms.

This condition is completely different from the objective of English teaching in SMK. Based on the Minister of Education and Culture Regulation No. 68, 69, 10/2013 about the basic competences of English states that English teaching in SMK is focused on developing communicative competence. The objective is to enable the students to communicate in the target language orally and in writing accurately and appropriately in the four language skills to support their competence in a certain 2 programs. To meet the basic competences in English teaching in SMK, it is important for the students to have English material that is suitable with their needs. The result about material is that the material should be suitable with their proficiency in English and also related to their vocational program.

Most of Culinary Department students grade $\mathrm{X}$ is lack of the knowledge about the words and expressions which are used in culinary terms. As we can see in the result that forty one percents of the students only know a little about the words or the expressions that used in culinary terms. They only know simple words like the name of the ingredients and the name of the tools that are use in the kitchen. They do not know some words or expressions that represent the condition of the food or the activities that they do in the kitchen like poach, beater, lump, boil, greasy, and many more. From this 
condition, the researcher concluded that the students need the material that explains more about the basic words and expressions in culinary terms and the material that can improve students' skills in English. Here are some examples of the specific words and expressions that needed by the students:

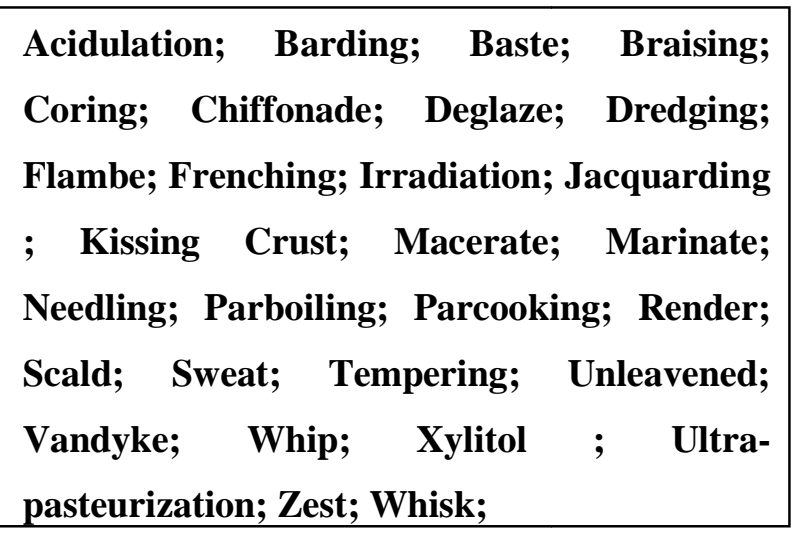

It is said that the objective of English teaching in SMK is to enable the students to communicate in the target language orally and in writing accurately and appropriately in the four language skills. To meet the objective, culinary department students need the learning activities which require the students to be more active for example discussing, reading text and role playing. From the result we can see that most of the students prefer the learning activities that require group or pair activity so they can be more active in class. Those activities can stimulate students in learning and demonstrate the theme of the material. Such activities can help the students to develop their four skills in English as well.

As we know, there are four skills in English that the students have to understand. In English teaching and learning process in SMK, speaking and reading are the skills that are considered as the skills which need to be served more for Culinary Department students. Those skills are the skills that are considered as the most important skills that are used a lot in their work field. Culinary Department students need to know how to explain the recipe or the work division to their cook helper and how to read a procedure text or recipe in the correct way to get the results that they want. In order to exploring students' speaking and reading skill, the teacher can use discussion, role playing and reading as learning activities.

For the teachers who teach Culinary department students, they are expected to be more active and motivate the students more, so the students can be more responsive in learning process. The teachers are also expected to teach with material and activity that are appropriate with the students' needs and the students' proficiency. Students also need some activities that require pair and group activities so they can practice their English with their friend in an enjoyable way.

From the result, the researcher concluded that Culinary Department students' need in English is a communicative and interesting learning process that is supported by appropriate materials and activities. The materials and activities should be related to their vocationnal program, Culinary Department. The materials and activities should be adapted from students' knowledge level. The materials that are suitable to the students are the materials that can provide more knowledge about culinary itself such as the words and expressions that are used in culinary, the correct procedure texts, and many more. The material have to contain more vocabularyy that is related to Culinary department like the name of kitchen tolls and the expressions that are used in Culinary such as overcooked, unripe, rotten, and many more. The material also have to contain more activities that can make the students learn in an active way like discussion, role playing, or idea sharing with their friends. The activities like reading, schamming or scanning the text is also need to support their skills.

\section{Unavaliable Needs in Textbook}

From the learners' need analysis result, students need a material that contain more vocabulary and grammar that related to culinary terms. Students also need learning activities that require the students to be more active in the class. But the condition in the learning process 
that happened in Culinary department class in SMKN 3 Bengkulu is different and far from the learners' need. The material that taught is a general material that doesn't suited with students in vocational school. In order to meets the learners' need, the researcher proposed a learning material that designed based on the learners' need and considered as the suitable material for Culinary department students.

From the graduates' point of view, the English needs of culinary department students are material that contains more vocabulary and grammar that related to the vocations. This opinion is supported with the teachers' opinion that stated about students' level proficiency. Most of the students of culinary department are lack of knowledge about the vocabulary and grammar that uses in Culinary terms like caramelized, branch, broil, and many more. This conditions compounded by the given material that does not contain any topics or themes that related to culinary terms. Teachers that taught culinary department used the book from Pusat Kurikulum dan Perbukuan, Balitbang, Kementerian Pendidikan dan Budaya. This book consists 18 chapters but none of the chapter contain any example or material that related with culinary department. The material in this book is the common material which is also studied by the students in public school.

Based on the result, then the researcher analyzed the textbook that used in Culinary department grade $\mathrm{x}$. The book published by Pusat Kurikulum dan Perbukuan, Balitbang, Kementerian Pendidikan dan Budaya. The researcher only compared the results of the reserach with the existing learning book for two reasons, first because the learners' needs in the English language focused more on the material and the learning activity and the second because there was no permission from the school to analyze the syllabus and the English course RPP used. The 10th grade culinary student receives English material from a book from Pusat Kurikulum dan Perbukuan, Balitbang, Kementerian Pendidikan dan Budaya, this book has 18 chapters. Each chapter in this book is a theme-based material based on the themes that related to everyday life such as talking about self, complimenting and care, expressing intentions, describing people and places, congratulating others and more. Each theme then divided into several aspects: warmer; Vocabulary builder; Pronunciation practice; Vocabulary exercises; Text structure; Grammar review; Skills; And review ;

After analyzing the book used the researcher found that the material taught does not contain words or expressions that related with the culinary terms. In the aspect of vocabulary builder and vocabulary excercises only emphasizes the common vocabulary used in the text of each theme example. No special vocabulary found like boil, caramelized, unripe, rotten and more. In the aspect of skills as well as these themes only contain a little learning activities that can help students in practice their English skills. The examples given such as text or conversation are also completely unrelated to culinary, while the results of student needs analysis undertaken at the Culinary Department at SMKN 3 Bengkulu states that students need learning materials that contain more vocabulary and grammar related to culinary. But in the learning process that implemented there is no material or learning activities in accordance with the results of student needs analysis. Such conditions are of course very influential on student achievement.

To meet the needs of students and to assist in completing the needs of students who are not yet available in the textbook, the researcher than proposes a learning material that is designed based on the learners' needs. This kind of learning material is designed based on the result if learners' need analysis, which means that this learning material is more suitable than the learning material before. This material can cover students' weaknesses by using the activities and the topics given to deepen their English skills and knowledge. This learning material is expected to be useful for helping the students in achieving the standards and deepen their English skills especially 
speaking and reading skills becausese those skills need to serve more in culinary.

This proposed learning material contains the relevant and significant topics, activities, and technique that are suitable with the learners' needs. The topics are adapted from the material that they learn in culinary class. This learning material is expected to be able to support the students in exploring their skills in English and enrich their vocabulary and grammar knowledge which are related to culinary terms. There are four elements in the proposed learning material. The elements are Topic; Skill; Sub-specific Topic; and Technique.

The first element is Topic. There are three main topics for this material. There are Basic of Culinary; Types of Food; and Food Nutrition. Those main topics are divided into some topics. The first topic, Basic of Culinary divided into five topics that are Knowledge of ingredients, knowledge of kitchen tools, Food processing techniques, Garnish, and Food serving. The types of food topics are divided into three topics that are Special opportunity food and Fusion food, Indonesian Food, and Continental Food. Those topics are chosen based on the material in their culinary class. The selected topics are the topics that are suitable with the students' proficiency and their needs and those topics considered as the topics that can support the students in exploring their English skills and help them in enrich their knowledge in English that related to Culinary terms.

For the skills, this elements are adjusted with the topics. For Culinary department students, speaking and reading are the skills that need to be serve more to support them in their future job. Each topic in this material is focused on exploring speaking and reading skills more than the other skills. This is also affected the learning process, because the learning process is focus more on the speaking and reading skills. This means the activities in the learning process are the activities that require the students to be more active like discussion, role play, and presentation. In this material, discussion and presentation are the techniques that are used more frequent in the learning process because those two activities are considered as the activities that can stimulate students to be more active in the learning process. Those two skills also can help the students in practice their English skills.

The chosen topics are then elaborated into some indicators for students in learning activities. Those indicators will show what the students need to know and what skills that the students have to achieve in the end of the learning activities for each topics. For example, in Knowledge of Ingredients topic, there are three indicators, first is describing the name of ingredients; second is grouping the ingredients based on the type; and the last is explaining the characteristics of ingredients by the type. Those indicators mean that the students have to be able to describe the name of ingredients in written or oral form, grouping the ingredients, and explain the characteristics. The indicators are also important to determine the type of activity or technique of learning for the students.

\section{Closing}

A descriptive qualitative research that was conducted trough Culinary department students in SMKN 3 Bengkulu city, the English teachers in SMKN 3 Bengkulu city, Culinary department's graduates and the stakehoder was finally answer the research questions of "what does the English needs of Culinary department students grade $X$ based on ESP?" and "how can the research finding be used to fullfil the learners' needs in English?" .

There are some results according to this research. First, students English needs based on ESP are the material that related to their vocations and contain more vocabulary and grammar that used in culinary terms, and also the material that needed by the students have to contain more tasks for the students to practice their English skills. Second, the needs that not avaliable in the textbooks mostly same with the laearners needs. The textbook does not contain any specific vocabulary related to Culinary terms 
and the tasks in the textbook emphasized more in general learning activities, while the culinary students need more vocabulary about culianry and the learning activities that focuses in speaking and reading skills as well as focuses in the activities that commonly happen in culinary terms.

According to the results of this research, the reseacher would like to give some suggestion. It is important for the English teachers to provide English materials for students by doing the needs analysis, up to date, and appropriate syllabus. It is important to do need analysis in order to identify students' needs. It is important to design the suitable material for the students. The teachers also can use the authentic material that related to culinary terms like the food recipe or food menu to provided the supplementary material that will be use to completing the needs that not avaliable in the textbook.

As this the first trial to Culinary department students, this could be a reference for those who are interested in doing the similar research.

\section{REFERENCES}

Alduais, A. M. S. (2012). Analysis of ESP Syllabus: Analysing the Book Basic English for Computing as a Sample and Testing its Suitability for ESP Learners in Public and Private Yemeni and Saudi Arabian Universities. International Journal of Academic Research in Business and Social Sciences, 2(11), 247.

Ampa, A. T., Rasyid, M. A., Rahman, A., \& Basri, M. (2013). The Students' Needs in Developing Learning Materials for Speaking Skills in Indonesia.

Anthony, Laurence and An Cheng.2014.

ESP in Asia. English for Specific Purposes, Volume +33, January 2014, Pages 1-3

Berwick, Richard. 1980. Needs Assessment in Language Programming: From Theory to Practice. In R.K. Johnson (ed), 1989, The Second Curriculum. Cambridge University Press, Cambridge.
Boroujeni, S. A., \& Fard, F. M. (2013). A Needs Analysis of English for Specific Purposes (ESP) Course For Adoption Of Communicative Language Teaching:(A Case of Iranian First-Year Students of Educational Administration). life, 1,

Brindley, Geoffrey. 1989. The Roles of Needs Analysis in Adult ESL Programme Design. In R.K. Johnson (ed), 1989, The Second Curriculum. Cambridge University Press, Cambridge.

Depdikbud. (2014). "Peraturan Menteri

Pendidikan dan Kebudayaan Republik Indonesia No. 60 tentang: Kurikulum 2013 Sekolah Menengah Kejuruan/ Madrasah Aliyah Kejuruan”. Jakarta.

Dudley-Evans, T., \& St John, M. J. (1998). Developments in English for specific purposes: A multi-disciplinary approach. Cambridge university press.

Holloway I, Wheeler S (2002) Qualitative Research in Nursing. 2nd edn. Blackwell, Oxford

Hutchinson, T. and Waters, A. 1987. English for Specific Purpose. Cambridge: Cambridge University Press.

Johns, A.M., \& Price-Machado, D. (2001). English for Specific Purposes (ESP): Tailoring courses to student needs-and to the outside world. In M. CelceMurcia (Ed.), Teaching English as a second or foreign language (3rd ed). Boston: Heinle \& Heinle.

Kebudayaan, P. M. P. D. (2013). Kerangka dasar dan struktur kurikulum sekolah menengah atas/madrasah Aliyah.

Khalik, L. A. (2014, May). ESP Needs Analysis Based Syllabus of Economics Faculty Students, Universitas "45" Makassar. In International Conference on Education and Language (ICEL) (Vol. 1).

Kustati, M., \& Zurniati, V. (2015). Needs Analysis for an (English for Specific Purposes (ESP) Subject (A Case Study of State Vocational High School 1 Padang). Research in English Language Teaching Journal, 1(1), 73-78. 
Kustati, M., \& Zurniati, V. (2015). Needs Analysis for an (English for Specific Purposes (ESP) Subject (A Case Study of State Vocational 
High School 1 Padang). Research in English Language Teaching Journal, 1(1), 73-78.

Kusumaningrum, L. (2010). An Analysis on the Learners' Needs of English Specific Purposes At SMK N 2 Sragen (Doctoral dissertation, Universitas Muhammadiyah Surakarta).

Long, M. H. (2005). Methodological issues in learner needs analysis (pp. 19-76). In M. $\mathrm{H}$. Long, (Ed.), Second language needs analysis. Cambridge: Cambridge University Press.

Robinson, P. C. (1991). ESP today: A practitioner's guide. Hemel Hempstead: Prentice Hall.
Rohmah, C. (2015). Developing English Learning Materials For Grade $X$ Students Of Marketing Study Program At SMK Muhammadiyah 2 Bantul. Universitas Negeri Yogyakarta

Songhori, M. H. (2008). Introduction to needs analysis. English for specific purposes world, 4, 1-25.

Swales, J. (1985). ESP in perspective: McDonough, Jo, A Practical Guide. London: Collins ELT, 1984, pp. 154. System, 13(3), 297299 